\title{
The Impact Of Transformational Leadership In Burnout Of Nurses And Doctors In A Public Hospital Of Mexico
}

\author{
Blanca Rosa García-Rivera, Universidad Autónoma de Baja California, México \\ Ignacio Alejandro Mendoza-Martínez, Universidad Autónoma de Baja California, México \\ María Concepción Ramírez- Barón, Universidad Autónoma de Baja California, México
}

\begin{abstract}
This study analyzes the relationship between supervisors' leadership styles and subordinates' experience of burnout. We tested relationships between transformational, transactional and non leadership styles and facets of burnout (i.e., emotional exhaustion, depersonalization and reduced personal accomplishment), using the Bass and Avolio and Maslach Models, while controlling for subordinates' demographics and hierarchical level. We applied the MLQ and MBI questionnaires to a sample of 102 employees in a Mexican Public Hospital to Doctors and Nurses. Our Structural Equations Models determined that inverse significant correlations were found between the different leadership subscales and burnout, excepting with those of the Laissez Faire, being positive. The theoretical and empirical findings of previous studies of the Model of Bass and Avolio, as well as of the Model of Maslach were reaffirmed; the subscale of depersonalization was eliminated. The reliability coefficients Alpha of Cronbach were higher than, 70 in all the variables.
\end{abstract}

Keywords: Transformational Leadership; Transactional Leadership; MLQ; MBI; Burnout; Emotional Exhaustion; Mexico

\section{INTRODUCTION}

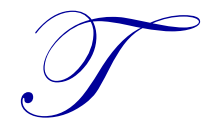

he relationship between leaders' behavior and subordinates' and their concomitant burnout has been increasingly the focus of attention from the scientific community (Bass, 1990; Gilbreath and Benson, 2004). Leadership style has an important influence in how subordinates cope with stress (Ryska, 2002). Leadership has been analyzed from the "new leadership paradigm" (Yukl, 2002) such as transformational leadership (Alban-Metcalfe and Alimo- Metcalfe, 2007; Bass, 1999; Harvey, Royal and Stout, 2003; Trautmann, Maher and Motley, 2007). Transformational leaders increase followers' motivation and promote positive emotions by creating and representing an inspiring vision of the future (Bass, 1985). Transactional leadership describes the relationship between leaders and followers from an exchange system of transactions. In this style, the leader rewards or disciplines the followers, taking account of their performance.

Although many studies have addressed the relationship between leadership styles and performance (Dumdum, Lowe and Avolio, 2002; Judge and Piccolo, 2004) the relationship between the behavior of leaders and their subordinates' and work-related burnout has mainly been neglected in developing countries like Mexico. Further, such studies on work-related burnout have been noticeably neglected in organizations that have nontraditional supervisory/subordinate relationships between the critical workers (hospitals), and also are located in developing countries.

The present study addresses this gap and explores the relationships between transformational, transactional and non-leadership styles and employees' experience of burnout. Using organizational data from an empirical study in a large public hospital in Mexico, we explain how different leadership styles relate to burnout within this population. 


\section{An Ancillary Complicating Factor}

The authors have conducted other research studies in organizations with more traditional hierarchical supervisor/subordinate organization charts. However, in health care organizations in general, and in hospitals in particular, the traditional supervisor/subordinate links do not exist in and between the caregiver personnel. The old "wobbly three-legged stool" organization comes into play. For instance:

- $\quad$ The line personnel, including the nurse caregivers, report managerially up through the organization chart (via the Nursing arm) to the hospital administrator.

- $\quad$ The doctor caregivers do not report managerially to the administrator.

- $\quad$ The doctors and nurses must work directly with each other, but the nurses do not report managerially to the doctors.

Although the nurses do not report to the doctors as a direct line, the doctors can foment conditions leading to a nurse's termination. Although there are many situations (i.e., emergency) where the doctors' leadership style must be authoritative over the nurses (who do not report to him or her), there are many situations where this style is not necessary; yet, the tendency may be for this style to be used in all interactions between the doctors and nurses.

The doctors do not report managerially to the administrator, and vice versa, yet the doctors in concert can often cause the termination of the administrator. Nurses feel obligated to support the administrator, to whom they report managerially, but feel obligated to support the doctors as mutual caregivers. Thus, they essentially feel allegiance to two "bosses." The conditions noted above exacerbate the difficulties in investigating the contribution of leadership styles between doctors and nurses to the burnout syndrome.

\section{Problem}

Leadership styles as well as factors that increase stress and burnout affect the behavior and performance of the health professionals and therefore the productivity in health organizations.

\section{Research Questions}

(1) Is the Model of Maslach validated in regards to the professional exhaustion of the doctors and nurses investigated? (2) Is the Model of Bass \& Avolio validated in regards to the subscales of transformational leadership in the supervisors investigated? (3) Is there a direct significant correlation between the subscales of transformational leadership of the supervisors with the subscales of professional exhaustion of the doctors and nurses participating in this research?

\section{Main Objective}

To correlate the Transformational Leadership sub-scales of a public health service districts using the model of Bass and Avolio, with the professional exhaustion sub-scales of doctors and nurses working there using the Maslach Model.

\section{Hypotheses}

Ho: Inverse, but not significant correlations are found between the subscales of emotional exhaustion, depersonalization and low personal achievement.

Ho (a): Inverse, but not significant correlations are found between the subscales of transformational leadership and resulting variables.

Ho (b) Positive, but not significant correlations are found between the subscale of Laissez Faire and resulting variables.

Ho (c) There is no direct significant correlation between the subscales of transformational and transactional leadership and resulting variables with the subscales of professional exhaustion as emotional exhaustion, de-personalization and low personal achievement. All the correlations between Laissez Faire and all the subscales of professional exhaustion are negative. 


\section{LITERATURE REVIEW}

\section{Leadership}

According to Bass (1990), more than 7500 studies in Leadership have been realized from the beginning of century XX, but the majority of those studies were made in the United States (Zander, 1997). In addition, there has been a great number of studies of leadership done outside the United States with approaches in the behavior of the leaders of specific countries, but Smiths and Peterson (1988) indicate that these investigators have been influenced in their majority by models and methods used in the United States (Zander, 1997).

\section{Burnout}

The syndrome of burnout is a combination of stressors that have their origin in the labor atmosphere and individual characteristics. (Gil Monte and Peiro, 1997). According to this author, burnout is considered a pathology (Gil Monte, 2001) that is derived from being exposed to chronic labor stress.

For the majority of authors, burnout is characterized by three dimensions: emotional exhaustion (progressive loss of the energy, fatigue, exhaustion, physical and/or psychological fatigue), de-personalisation (negative attitudes, irritability, loss of the motivation and incompetence) and lack of accomplishment in the work (that involves negative answers towards itself and the work) (Maslach 1981; Gil Monte 2001).

The Syndrome of Burnout has been studied in personnel of different professions. It has been observed that it is a phenomenon that appears very frequently in nurses (Solano, Hernández, Vizcaya, and Reig, 2002), psychiatrists (Kumar, Fischer, Robinson, Hatcher \& Bhagat, 2007), advisors (Kirk-Brown \& Wallace, 2004), civil servants of prisons, psychologists (Gomes \& Cruz, 2004), police (Silveira, ET. to., 2005) and educators (Arís, 2009), among others. (Friedman, 2002; Tejero, 2005; Tejero, Fernandez \& Carballo, 2010).

\section{The Maslach Model of Burnout}

Based on Freudenberger (1975) and Maslach (1976) work, the MBI explains burnout as a psychological syndrome that responds to chronic stressors on the job (Maslach, Schaufeli, \& Leiter, 2001). The three key dimensions of this response are (1) emotional exhaustion (EE, the feeling of being overextended and depleted of resources, representing the basic individual stress dimension of burnout), (2) depersonalization (DP, a cynical and distant attitude towards one's work and the people one works with, representing the interpersonal context in which burnout occurs), and (3) reduced personal accomplishment (PA, the tendency to evaluate one's achievements at work negatively, thus referring to the self-evaluation dimension of burnout). EE is usually considered to be the central quality of burnout and the most obvious manifestation of the syndrome.

\section{METHODS}

\section{Data and Sample}

The study was done among 102 nurses and doctors from a Public Health Hospital in Baja California, Mexico. In agreement with the general management of the hospital, a questionnaire was designed to assess leadership and emotional exhaustion, using the scales of Maslach and Bass and Avolio. Each questionnaire was delivered in hand to the surveyed employees explaining the purpose of the study and providing assurance that the confidentiality of responses would be respected. Out of the 150 questionnaires delivered, 102 usable ones were returned, giving a $68 \%$ response rate. Nonetheless, we compared demographic data (age, sex, tenure, full time/part time status) between our sample and the whole nursing and doctor population of the hospital, based on information received from the director. No significant difference was detected. We are thus confident that our results do not contain any apparent systematic bias. Among respondents, mean age was 35 years, and mean hospital tenure was 6.5 years. $70.6 \%$ (72) of respondents were female. 


\section{Research instruments}

\section{Leadership}

The Multifactor Leadership Questionnaire (MLQ, form 5, Bass \& Avolio 1991) was used to measure leadership behaviors in this study. The MLQ-5 includes 52 items providing descriptions of transactional and transformational behaviors. A 5-point response scale ranging from never (0) to always (5) was used for all items. For purpose of the study, an Spanish version of the MLQ-5 was used, based on a standard translation-backtranslation procedure. This ensured that major misunderstandings caused by translation would be avoided (Peng, Peterson, and Shyi, 1991). Moreover, we had conducted previously a validation study of the MLQ in Spanish, in which we found correlations with work outcomes of the same magnitude and direction as those traditionally found using the English version (Stordeur, Vandenberghe and D'hoore, 2000). Transformational dimensions included charisma (eight items; e.g. 'his/her actions build my respect for him/her'), idealized influence (10 items; e.g. `talks to us about his/her most important values and beliefs'), inspirational role (10 items; e.g. 'talks enthusiastically about what needs to be accomplished'), intellectual stimulation (10 items; e.g. 'encourages nontraditional thinking to deal with traditional problems'), and individualized consideration (nine items; e.g. 'treats each of us as individuals with different needs, abilities and S. Stordeur et al.aspirations'). Three dimensions defined transactional leadership: contingent reward (nine items; e.g. 'makes sure that we receive appropriate rewards for achieving performance targets'), MBEA (seven items; e.g. 'directs his/her attention towards failure to meet standards'), and MBEP (seven items; e.g. 'things have to go wrong for him/her taking action'). For all dimensions, a mean score was calculated for each respondent by averaging across the items composing the corresponding scale.

\section{Emotional exhaustion and burnout}

This was measured using a scale of the Maslach Burnout Inventory (Maslach \& Jackson 1981). This scale included 22 items (e.g. 'I feel emotionally drained from my work'). Respondents indicated the frequency to which they experienced the state depicted in the items, using a scale ranging from 1 ('never') to 7 ('every day'). Results are reported in the form of total scores for the whole scale. Experienced levels of emotional exhaustion fall on a continuum ranging from 9 to 63 . Maslach \& Jackson (1981b) additionally report cutoff data for categorizing scores in nursing settings as high $(>29)$, moderate $(18 \pm 29)$, or low $(<18)$ in emotional exhaustion.

The questionnaire details and other research question answers are available from the senior author.

Data analysis

The data were analyzed using Structural Equation Modeling (SEM) using the SPSS and AMOS programs. Also Multiple Regression was used to evaluate each model. The reliability of the variables was evaluated using the Alpha of Cronbach Coefficient.

\section{RESULTS}

\section{Results for Hypothesis No. 1}

The null model for Hypothesis 1 tested the relationship between the subscales of emotional exhaustion, depersonalization and reduced personal accomplishment. To examine that our results are robust across different models, we used SEM to compare alternative models. The first model (SEM 1) estimated was the hypothesized model. In this model, we tested the relationship between the subscales of emotional exhaustion, depersonalization and reduced personal accomplishment. The initial SEM results were: $\mathrm{X} 2=345.435, \mathrm{P}($ d.f. $)=206, \mathrm{p}=0 \mathrm{CMIN} / \mathrm{DF}$ $=1.677$, and RMSEA $=0.082 ; \mathrm{NFI}=0.641, \mathrm{TLI}=0.786, \mathrm{CFI}=0.809, \mathrm{GFI}=0.775, \mathrm{AGFI}=0.723$. 


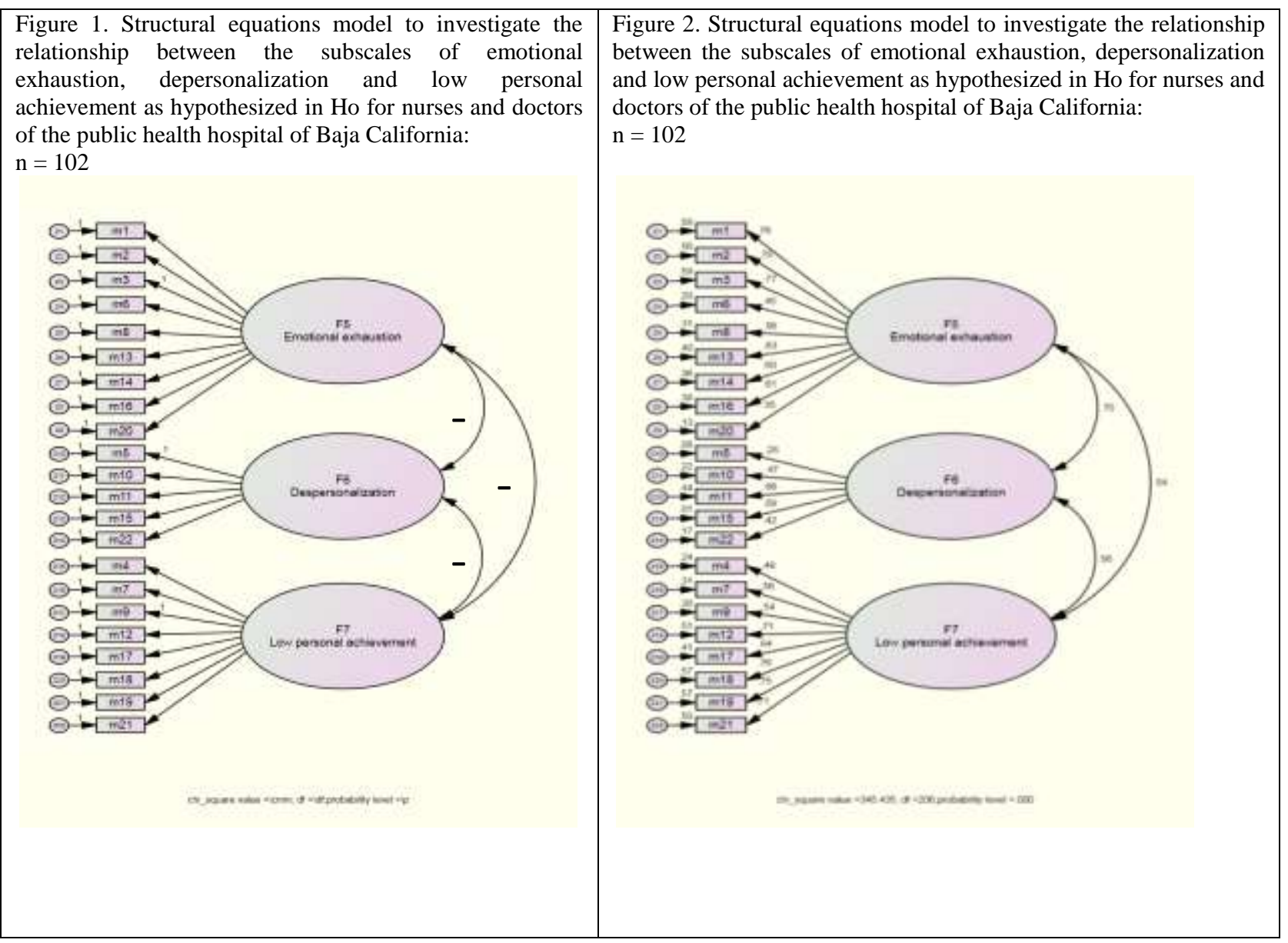

Table 1. Indices obtained from structural equations analysis of figure 1 and 2.

\begin{tabular}{ccccccccccc}
\hline Estadísticos & $\chi^{2}$ & D.F. & $P$ & CMIN/DF & RMSEA & NFI & TLI & CFI & GFI & AGFI \\
\hline Modelo hipotetizado & 345.435 & 206 & 0 & 1.677 & 0.082 & 0.641 & 0.786 & 0.809 & 0.775 & 0.723 \\
\hline
\end{tabular}

The initial hypothesized model was adjusted and a new re-specified model was integrated (SEM 2), Figure 3 shows the new structural equations model re-specified. 
Figure \# 3. Structural equations model re-specified to investigate the relationship between the subscales of emotional exhaustion, depersonalization and low personal achievement as hypothesized in Ho for nurses and doctors of the public health hospital of Baja California: $\mathrm{n}=102$

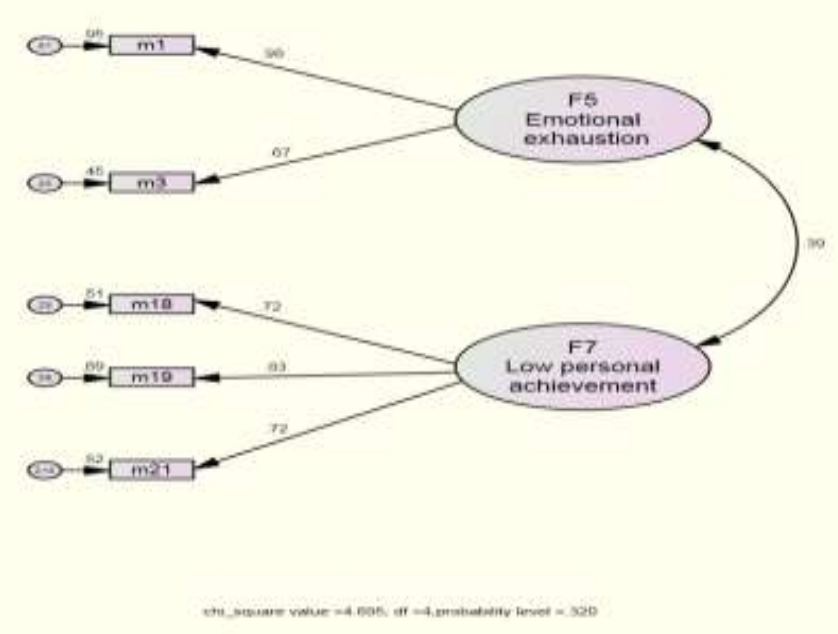

Table \# 2. Indices of the model

\begin{tabular}{ccccccccccc}
\hline Estadisicicos & $X^{2}$ & D.F. & $P$ & CMNNDF & RMSEA & NFI & TLL & CFI & CFI & AGFI \\
\hline Modelohipotetizado & 4.695 & 4 & 0.32 & 1.174 & 0.041 & 0.972 & 0.989 & 0.996 & 0.982 & 0.933 \\
\hline
\end{tabular}

Table 3. Standardized Regression Weights

\begin{tabular}{lllcccc}
\hline & & Variables & Estimate & Error & Critical & P \\
& & & & S.E. & (C.R.) & \\
\hline $\mathrm{m} 1$ & $<--$ & F5_Cansacio_emocional & 1.42 & 0.46 & 3.12 & 0.002 \\
$\mathrm{~m} 18$ & $<--$ & F7_Baja realización_personal & 0.92 & 0.14 & 6.37 & $* * *$ \\
$\mathrm{~m} 21$ & $<--$ & F7_Baja realización_personal & 1.05 & 0.17 & 6.40 & $* * *$ \\
\hline$* * * * 0.001$ & & & & &
\end{tabular}

\begin{tabular}{llll}
\hline & \multicolumn{1}{c}{ Variables } & Pesos \\
\hline m1 & $<---$ & F5_Cansacio_emocional & 0.98 \\
m3 & $<--$ & F5_Cansacio_emocional & 0.67 \\
m18 & $<---$ & F7_Baja realización_personal & 0.72 \\
m19 & $<---$ & F7_Baja realización_personal & 0.83 \\
m21 & $<---$ & F7_Baja realización_personal & 0.72 \\
\hline
\end{tabular}

Table \# 4. Correlation Matrix:

\begin{tabular}{|c|c|c|c|}
\hline & Correlación & & Estimación \\
\hline F5_Cansacio_emocional & $<-->$ & $\begin{array}{c}\text { F7_Baja } \\
\text { realización_personal }\end{array}$ & 0.39 \\
\hline
\end{tabular}

The results indicate fit indexes for SEM 2: X2 = 4.695, P(d.f. $)=4, \mathrm{p}=0.32 \mathrm{CMIN} / \mathrm{DF}=1.174$, and RMSEA=0.041; $\mathrm{NFI}=0.972, \mathrm{TLI}=0.989, \mathrm{CFI}=0.996, \mathrm{GFI}=0.982, \mathrm{AGFI}=0.933$. 
As noted above, Table \# 2, shows a decrease in Chi square of the initial model from 345.435 to 4.695 , in the re-specified model. CMIN/DF of 1.174 confirms an excellent model, RMSEA of 0.041 confirms a good adjustment to a trust interval of 95\%, indices NFI, TLI, DFI, GF1 and AGFI close to 1 being good, support and confirm the kindness of the adjustment. Table \# 3, shows significant standardized beta coeficients above 0.70 in every factor of the final model. It is important to mention that the subscale of depersonalization was not significant and it was necessary to remove it from the SEM while re-specifying and adjusting as shown in SEM 2.

Table 4, shows a direct significant correlation of 0.39 between emotional exhaustion and reduced personal accomplishment. Alfa Cronbach Coeficients for the subscales of emotional exhaustion and reduced personal accomplishment for the final model were: for emotional exhaustion $=0.79$ and for low personal achievement $=$ 0.79. According to the above analysis, Ho for Hypothesis No. 1 was rejected, with a $\mathrm{P}=0.05$.

\section{Results for Hypothesis No. 2}

The null model for Hypothesis 2 tested the relationship between the subscales of Transformational, Transactional and Laissez Faire Leadership with result variables. To examine that our results are robust across different models, we used SEM to compare alternative models. The first model (SEM 3) estimated was the hypothesized model. The initial SEM 3 results were: $\mathrm{X} 2=236.096, \mathrm{P}(\mathrm{d} . \mathrm{f}$. $)=129, \mathrm{p}=0 \mathrm{CMIN} / \mathrm{DF}=1.83$, and RMSEA $=0.091 ; \mathrm{NFI}=0.9, \mathrm{TLI}=0.943, \mathrm{CFI}=0.952, \mathrm{GFI}=0.952, \mathrm{AGFI}=0.737$.

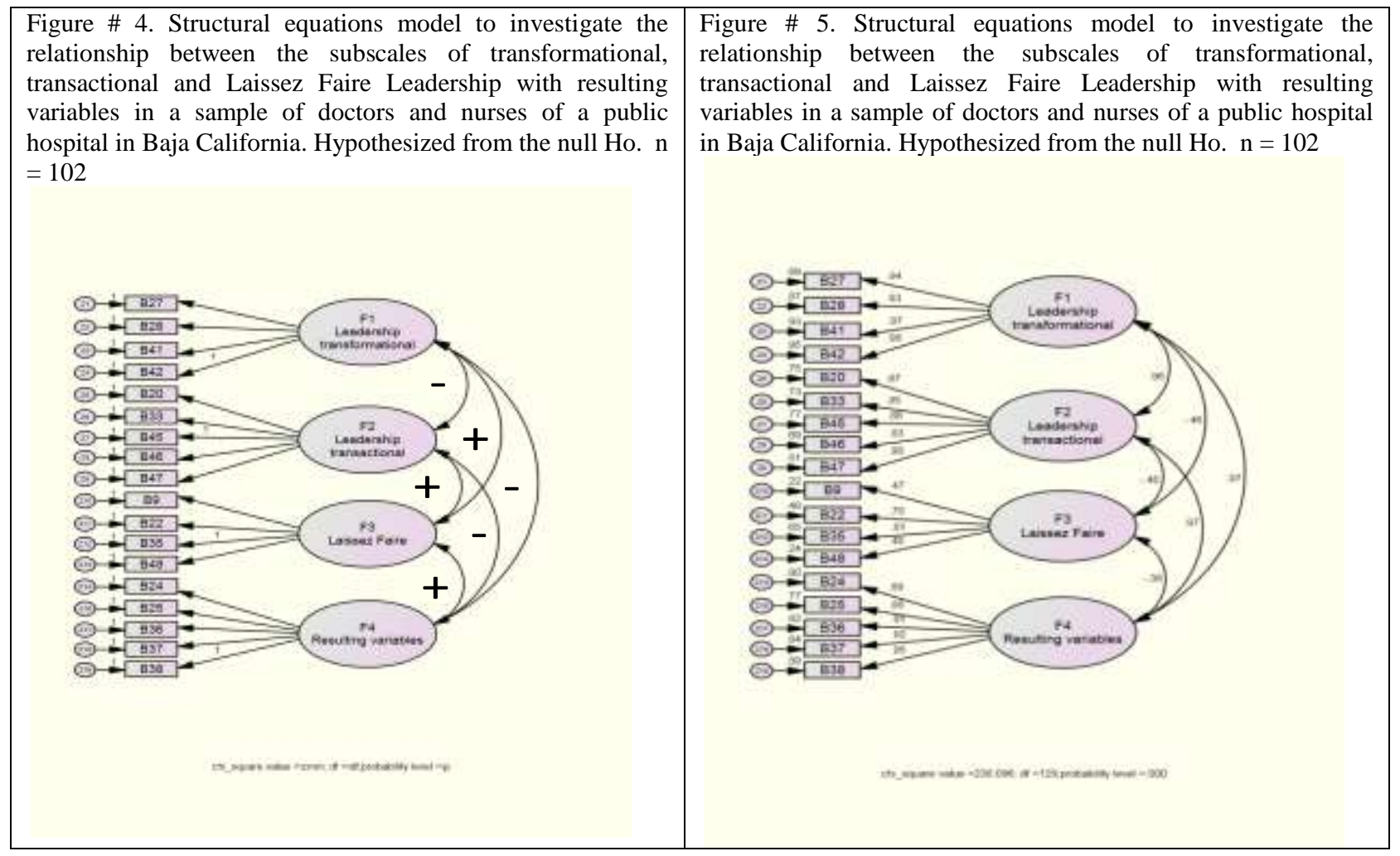

Table \# 5. Indices of the Model

\begin{tabular}{ccccccccccc}
\hline Estadísticos & $\mathbf{X}^{2}$ & D.F. & $\mathbf{P}$ & CMIN/DF & RMSEA & NFI & TLI & CFI & GFI & AGFI \\
\hline Modelo hipotetizado & 236.096 & 129 & 0 & 1.83 & 0.091 & 0.9 & 0.943 & 0.952 & 0.952 & 0.737 \\
\hline
\end{tabular}

The initial hypothesized model was adjusted and a new re-specified model was integrated (SEM 6), Figure 4 shows the new structural equations model re-specified. 


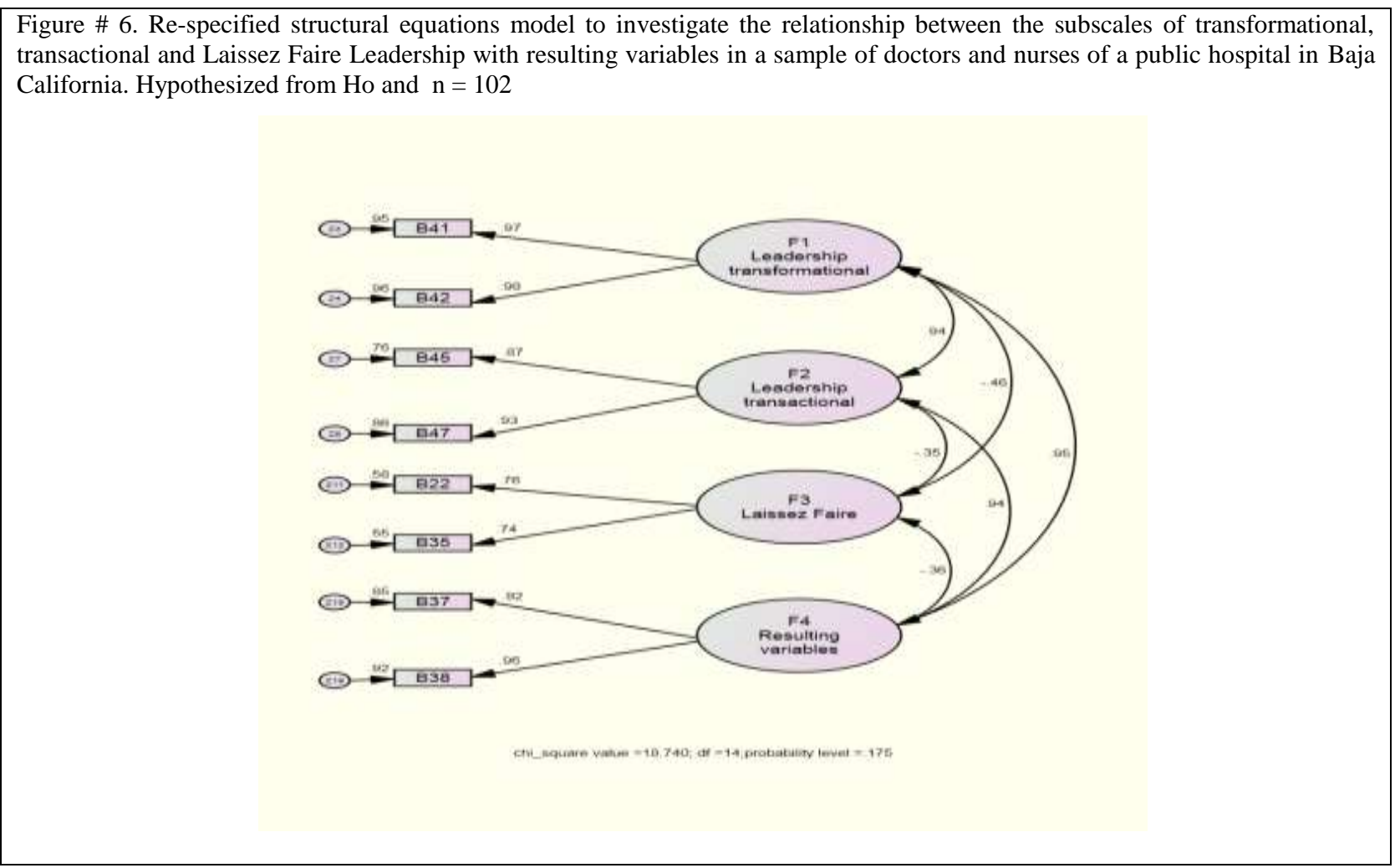

Table \# 6. Indices of the Model

\begin{tabular}{ccccccccccc}
\hline Estadisticos & $X^{2}$ & D.F. & $P$ & CMNNDF & RMSEA & NFI & TLI & CFI & GFI & AGFI \\
\hline Modelo hipotetizado & 18.74 & 14 & 0.175 & 1.339 & 0.058 & 0.98 & 0.989 & 0.995 & 0.959 & 0.895 \\
\hline
\end{tabular}

Table \# 7. Standardized Regression Weights

\begin{tabular}{|c|c|c|c|c|c|c|}
\hline \multicolumn{3}{|r|}{ Variables } & Estimate & $\begin{array}{l}\text { Error } \\
\text { estándar } \\
\text { S.E. }\end{array}$ & $\begin{array}{l}\text { Cititical } \\
\text { radio } \\
\text { (C.R.) }\end{array}$ & $p$ \\
\hline$B 41$ & $<\cdots$ & F1_L_iderazzo__ransformacional & 1.00 & 0.03 & 30.49 & *** \\
\hline B47 & $<-\cdots$ & F2_Liderazzo_ Transaccional & 1.00 & 0.07 & 13.73 & * * * \\
\hline B22 & $<\cdots$ & F3_laissez Faire & 0.81 & 0.20 & 4.00 & *** \\
\hline B37 & $<\cdots$ & F4__ariables_de resultado & 1.02 & 0.06 & 18.50 & $* * *$ \\
\hline
\end{tabular}

\begin{tabular}{lllc}
\hline & & \multicolumn{1}{c}{ Variables } & Pesos \\
\hline B42 & $<--$ & F1_Liderazgo_Transformacional & 0.98 \\
B41 & $<--$ & F1_Liderazgo_Transformacional & 0.97 \\
B47 & $<--$ & F2_Liderazgo_Transaccional & 0.93 \\
B45 & $<--$ & F2_Liderazgo_Transaccional & 0.87 \\
B22 & $<--$ & F3_Laissez Faire & 0.76 \\
B35 & $<--$ & F3_Laissez Faire & 0.74 \\
B37 & $<--$ & F4_Variables_de resultado & 0.92 \\
B38 & $<--$ & F4_Variables_de resultado & 0.96 \\
\hline
\end{tabular}

Table \# 8. Correlation Matrix

\begin{tabular}{lcccc}
\hline \multicolumn{1}{c}{ Subescalas de liderazgo } & F4 & F3 & F2 & F1 \\
\hline F4_Variables_de resultado & 1 & & & \\
F3_Laissez Faire & -0.36 & 1 & & \\
F2_Liderazgo_Transaccional & 0.942 & -0.349 & 1 & \\
F1_Liderazgo_Transformacional & 0.946 & -0.462 & 0.94 & 1 \\
\hline
\end{tabular}

The results indicate fit indexes for SEM 4: X2 $=18.74, \mathrm{P}($ d.f. $)=14, \mathrm{p}=0.175 \mathrm{CMIN} / \mathrm{DF}=1.339$, and RMSEA= $0.058 ; \mathrm{NFI}=0.98, \mathrm{TLI}=0.995, \mathrm{CFI}=0.995, \mathrm{GFI}=0.959, \mathrm{AGFI}=0.895$. 
As noted above, Table 6, shows a decrease in Chi square of the initial model from 236.096 to 18.74, in the re-specified model. CMIN/DF of 1.339 confirms an excellent model, RMSEA of 0.058 confirms a good adjustment to a trust interval of $95 \%$, indices NFI, TLI, DFI, GF1 and AGFI close to 1 being good, support and confirm the kindness of the adjustment. Table \# 7, shows significant standardized beta coeficients above 0.70 in every factor of the final model.

Table 8 shows highly significant correlations between transformational, transactional leadership and result variables higher than 90. Inverse significant correlations between laissez faire and all other subscales were found as follows: with result variables, correlation was -0.36 , with transactional leadership it was -0.349 , and with transformational leadership it was of -0.462. Alfa Cronbach Coeficients for the subscales of transformational and transactional leadership for the final model were: for transformational leadership $=0.98$ and for transactional leadership $=0.89$. For Laissez Faire $=0.71$ and for result variables $=0.94$. According to the above analysis, Ho. for Hypothesis No. 2 was rejected, with a $\mathrm{P}=0.10$.

\section{Results for hypothesis No.3}

The null model for Hypothesis 3 tested the relationship between the subscales of Transformational, Transactional and Laissez Faire Leadership with result variables and emotional exhaustion, depersonalization and reduced personal accomplishment. To examine that our results are robust across different models, we used SEM to compare alternative models. The first model (SEM5) estimated was the hypothesized model. The initial SEM5 results were: $\mathrm{X} 2=58.184, \mathrm{P}($ d.f. $)=50, \mathrm{p}=0.199 \mathrm{CMIN} / \mathrm{DF}=1.164$, and RMSEA $=0.04 ; \mathrm{NFI}=0.95, \mathrm{TLI}=0.992$, $\mathrm{CFI}=0.952, \mathrm{GFI}=0.927, \mathrm{AGFI}=0.867$.

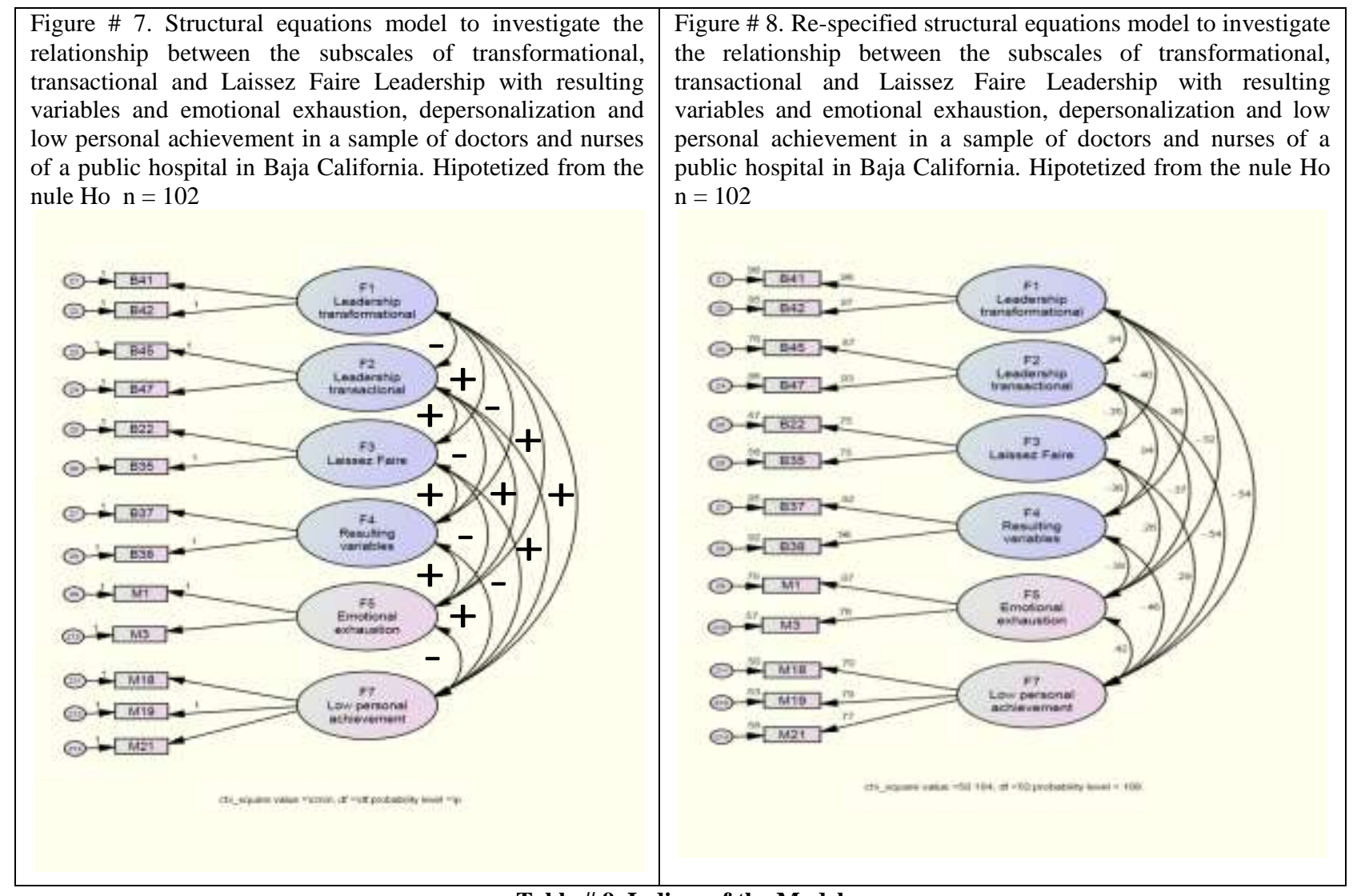

Table \# 9. Indices of the Model

\begin{tabular}{ccccccccccc}
\hline Estadísticos & $X^{2}$ & D.F. & $P$ & CMIN/DF & RMSEA & NFI & TLI & CFI & GFI & AGFI \\
\hline Modelo hipotetizado & 58.184 & 50 & 0.199 & 1.164 & 0.04 & 0.95 & 0.988 & 0.992 & 0.927 & 0.867 \\
\hline
\end{tabular}


The initial hypothesized model was adjusted and a new re-specified model was integrated. Table 9 shows a decrease in Chi square in the initial model from the 58.184 in the re-specified model. CMIN/DF of 1.164 confirms an excellent model, RMSEA of 0.04 confirms a good adjustment to a trust interval of $95 \%$, indices NFI, TLI, DFI, GF1 and AGFI close to 1 being good, support and confirm the kindness of the adjustment. Figure 8 and Table 10 how significant standardized significant beta coeficients above 0.70 with a P. $<0.05$ in all factors involved for subscales of transformational leadership and professional exhaustion.

Figure 8 and Table 11 show highly significant correlations among transformational leadership, transactional leadership and resulting variables higher than 0.90. Significant moderate inverse correlations were found between Laissez Faire leadership and all the other subscales from -0.35 to -0.46 . In regards to correlations between the Laissez Faire leadership with subscales of professional exhaustion, we observed that there is a direct significant correlation of 0.26 and with reduced personal accomplishment of 0.29 .

Correlation between emotional exhaustion and transformational leadership was of -0.32 . Correlation between emotional exhaustion and transactional leadership was of -0.27 and with result variables was of -0.39 . According to the above analysis, Ho for Hypothesis No. 3 was rejected, with a $\mathrm{P}=0.05$.

\section{DISCUSSION}

As noted early on, the unorthodox reporting relationship between the doctors and nurses in the study make it more difficult to draw some of the conclusions of this research. To review, the nurses do not report to the doctors, managerially; rather, they report up the administrative/managerial arm of the organization chart. Thus, the doctors, since they do not report to the administrator, do not hold the traditional supervisory authority over the nurses and their positions. Yet, the doctors hold more than a modicum of influence over the nurses and their performance of their duties. These aspects of the doctor/nurse relationship must enter into the observations drawn from the research's outcomes.

Yet, their non-traditional supervisor/subordinate interactions notwithstanding, there is no doubt the doctors' and the nurses' duties, coupled with their interactions, lead to a great deal of stress and burnout. Thus, although the exact managerial and leadership sources of the stress and burnout may be arguable, they exist, and it is believed the following conclusions drawn from the research are apropos. The Maslach model with regard to professional doctors' and nurses' stressors is validated because we found significant direct correlations between the scales of emotional exhaustion, depersonalization, and low personal fulfillment in the investigated workers. It is important to note that the structural equations model eliminated the subscale of depersonalization.

The results validated the transformational leadership model of Bass and Avolio, because we found significant direct correlations among the subscales of transformational leadership, transactional leadership and outcomes. In contrast, we found significant inverse correlations with the Laissez Faire style in the investigated workers. The Cronbach $\alpha$ coefficient of reliability for each of the subscales of the transformational leadership model of Bass and Avolio reached levels higher than 0.70, as did the two scales in the Maslach model. There is a significant inverse correlation between subscales of the transformational leadership, transactional, and outcomes, with the scales of professional wear such as emotional fatigue and low personal fulfillment. The correlations between Laissez Faire and the scales of professional wear that were in the model are positive.

The findings suggest that transformational leadership has a significant positive association with personal accomplishment and is negatively associated with emotional exhaustion and depersonalization. In addition, a positive relationship exists between passive avoidance leadership and emotional exhaustion and depersonalization. Finally, individuals with a passive avoidance leadership style exhibited higher levels of burnout.

Jennings, Disch, and Senn have noted, "Reports from the Institute of Medicine (IOM) have emphasized that leadership is essential to achieving goals related to quality care and patient safety." Thus, styles of leadership impacting the two major groups of care-givers in hospitals; i.e., doctors and nurses, and the accompanying stress and burnout in these two populations, are very important in research studies. In addition to leadership styles, current initiatives within hospitals along the lines of doctor-nurse collaborative teams, intervention of unionization between 
the individual caregiver and his or her stressor, and other initiatives to mitigate the sources of stress and burnout, are very worthy of research. Finally, styles of leadership, coupled with organizational aspects of a country's health care and the overall country-specific culture and attitude toward health care providers, could provide major topics of research leading to adjustments in each area and contributing to a reduction in burnout.

\section{AUTHOR INFORMATION}

Blanca Rosa García-Rivera, Universidad Autonoma de Baja California, Mexico. E-mail: blanca_garcia@hotmail.com (Corresponding author)

Ignacio Alejandro Mendoza-Martínez, Universidad Autonoma de Baja California, México

María Concepción Ramírez Barón, Universidad Autónoma de Baja California, Mexico

\section{REFERENCES}

1. Arís, N. (2009). El Síndrome de Burnout en los docentes. Electronic Journal of Research in Educational Psychology, 7(2), 829-848.

2. $\quad$ Bass, B. M. and Avolio, B. J. (1991). Multifactor Leadership Questionnire (form 5X. self). Center for Leadership Studies. School of Management. Binghamton University.

3. $\quad$ Bass, B.M. (1985). Leadership: good, better, best. Organizational Dynamics. 13(3), 26-40.

4. Bass, B.M. (1990) From transactional to transformational leadership: learning to share the vision. Organizational Dynamics, 18(3), 19-31.

5. Bass, B.M. (1997). Does the transactional-transformational leadership paradigm transcend organizational and national boundaries? Journal of American psychologist, 52(2), 130-139.

6. Dumdum, U. R., Lowe, K. B., \& Avolio, B. J. (2002). A meta-analysis of transformational and transactional leadership correlates of effectiveness and satisfaction: An update and extension.

7. Friedman, I. (2002). Burnout in School Principals: Role Related Antecedents. Social Psychology of Education, 5(3), 229-251

8. Gil Monte, P.R. and Peiro, J. (1997) Desgaste psíquico en el trabajo: el síndrome de quemarse. Madrid: Editorial Síntesis.

9. Gilbreath, B. \& Benson, P. G. (2004). The contribution of supervisor behavior to employee psychological well-being. Work \& Stress, 18, 255-266.

10. Gil-Monte, P. R. (2001, 25 de julio). El síndrome de quemarse por el trabajo (síndrome de burnout): aproximaciones teóricas para su explicación y recomendaciones para la intervención. Revista PsicologiaCientifica.com, 3(5). http://www.psicologiacientifica.com/bv/psicologia-78-1-el-sindrome-dequemarse-por-el-trabajo-(sindrome-de-burnout)

11. Gomes, A. R. and Cruz, J. F. A. (2004), A experiência de stresse e "burnout" em psicólogos portugueses: um estudo sobre as diferenças de género, Psicologia : teoria, investigação e prática, 9, (2), 193-212.

12. Harvey, S., Royal, M., and Stout, D. (2003). Instructor`s transformational leadership: University student attitudes and ratings. Psychological Reports, 92, 395-402.

13. Jennings, B., Disch, J., and Senn, L., Patient Safety and Quality: An Evidence-Based Handbook for Nurses. AHRQ Publication No. 08-0043, April 2008. Agency for Healthcare Research and Quality, Rockville, MD. http://www.ahrq.gov/qual/nurseshdbk/

14. Judge, T. A. and Piccolo, R. F. (2004). Transformational and transactional leadership: A meta-analytic test of their relative validity. Journal of Applied Psychology, 89, 755-768.

15. Kirk-Brown, A. and Wallace, D. (2004). Predicting burnout and job satisfaction in workplace counselors: the influence of role stressors, job challenge, and organisational knowledge. Journal of Employment Counseling, 41(1), 29-38.

16. Kumar, Fischer, Robinson, Hatcher and Bhagat (2007) Burnout and job satisfaction in New Zealand psychiatrists: a national study. International Journal of Social Psychiatry July 2007 53: 306-316,

17. Maslach, C. y Jackson, S. (1981) Maslach Burnout inventory. Palo Alto, California: Consulting Psychologists Press. 
18. Maslach, C., Leiter, P. and Schaufeli (2001) Job Burnout, Annual Review of Psychology. Vol.52, pgs. 357422.

19. Peng, T.K., Peterson, M.F. and Shyi, Y.P. (1991) quantitative methods in cross-national management research: trends and equivalence issues. Journal of Organizational Behavior, 12: 87-107.

20. Ryska, T. A. (2002). Leadership styles and occupational stress among college athletic directors: The moderating effect of program goals. Journal of Psychology, 136, 195-213.

21. Silveira, N. M. et al. (2005). Avaliação de burnout em uma amostra de policiais civis. Revista de Psiquiatria do Rio Grande do Sul, 27, (2), 159-163

22. Smiths, P.B. and Peterson, M.F. (1988) Leadership, organizations, and culture: An event management model, Sage Publications.

23. Solano, M. C., Hernández, P., Vizcaya, M. F. \& Reig, A. (2002). Síndrome de Burnout en profesionales de enfermería de cuidados críticos. Enfermería Intensiva, 13(1), 9-16.

24. Stordeur, S., Vandenberghe, C., D'hoore, W. (2000) Leadership styles across hierarchical levels in nursing departments. Nursing Research (2000) Volume: 49, Issue: 1, Pages: 37-43

25. Tejero, C. M. (2005). Burnout y dirección escolar. Análisis de la influencia que sobre el síndrome ejercen las variables: perfil demográfico profesional, estrés, satisfacción e indefensión. Resumen de Tesis Doctoral de la Universidad Complutense de Madrid.

26. Tejero, C. M., Fernández, M. J. \& Carballo, R. (2010). Medición y prevalencia del síndrome de quemarse por el trabajo (burnout) en la dirección escolar. Revista de Educación, 351, 361-383.

27. Trautmann, K., Maher, K. J., and Motley, D. G. (2007). Learning strategies as predictors of transformational leadership: the case of nonprofit managers. Leadership \& Organization Development Journal, 28, 269-287.

28. Yukl, G. (2002). Leadership in organizations. (5th ed.) Upper Saddle River, NJ: Prentice HallAlbanMetcalfe, R. J. \& Alimo-Metcalfe, B. (2007). Development of a private sector version of the (Engaging) Transformational Leadership Questionnaire. Leadership \& Organization Development Journal, 28, 104121.

29. Zander, L. (1997) The Licence to Lead: An 18 country Study of the Relationship between Employees'preferences Regarding Interpersonal Leadership and National Culture', Stockholm 